\title{
Construction of International Threat on UN Charter to Prevent an Unjust War
}

\author{
Arief Rachman Hakim ${ }^{1, *}$, Elisabeth Septin Puspoayu ${ }^{2}$, and Dananggana Satriatama ${ }^{3}$ \\ ${ }^{1}$ Student of Law Postgraduate Program, Diponegoro University, Semarang, Indonesia \\ ${ }^{2}$ Lecturer of Law Department, State University of Surabaya, Surabaya, Indonesia \\ ${ }^{3}$ Student of Law Department, State University of Surabaya, Surabaya, Indonesia
}

\begin{abstract}
Article 39 on the UN Charter mentioned that Security Council has an authority to determine any threat to the peace, breach of peace or act of aggression and so on. That Article has an implicit purpose that any country which wage a war or support an armed conflict without the SC authorization are considered as breach on other country's territorial or political integrity as mentioned at Article 2.4. It can be classified as an Unjust War. The Unjust War itself can cause a major impact to destroy another country's sovereignty and moreover the devastation from war often cannot be approximated. This paper used normative or doctrinal legal research method. Furthermore, it will reconstruct the authority of the UN to reformulate the international threat to prevent future commence of Unjust War with a political law. The main aspects to reconstruct must be linked to whether the removal of veto rights or political mechanism via UN General Assembly. While, the expansion of the authority to propose a sanction in the UN is not only coming from SC initiative only but it can be reconstructed so that the authority via UN GA can make a bigger sovereign and equally legally decision against big countries' political power.
\end{abstract}

\section{Introduction and literature review}

At the very beginning of the human life as a society there will be always a conflict between each other and in several scopes, it ends to destruction. A destruction caused by arising conflict can be seen when there is a country which cannot solve its problem or dispute with a modest way without any harmful methods. History has written that the biggest war that human being ever conducted is the occurrence of World War II which caused around 50 million civilians and military dead, and much others suffered, while nowadays, we can still read at many historical references about it. The break out of the World War II is nothing but the failure of many nations who gathered in League of Nations to prevent a sign of war, waging from the member itself. Post-World War II with that kind of failure, countries of the world tried to minimize or even dissolve the possibility to waging a war with others by made of international organization in which it has authorities to determine or help to settle the dispute or determine the act which is categorized as breach of peaceful world order.

\footnotetext{
*Corresponding author: arief.hakim0893@gmail.com
} 
The United Nations (here in after referred as UN) is an organization established to promote the international peace and security through a system of collective security [1]. The United Nations itself consists of several sub-organizations that support the running of the international organization to achieve its objectives in accordance with the Charter of the United Nations which was approved by the states on October 24, 1945. The important of the UN organization that support the implementation of the UN to avoid conflict among its countries member are reflected by the establishment of the UN Security Council (hereinafter referred as UNSC). It is one of the UN organizations which have a legally binding decision when it has been approved by its members. Normatively, arrangements regarding to the UN Security Council are regulated in Chapter V of the UN Charter, where in Article 25 is implicitly said that the decision of the UNSC is legally binding, even though there are no words explicitly that every decision is bond to every nations or aspects of the decision which was made before.

\subsection{International Threat and The Authority to Determine}

As explained above, that the UNSC is the only organization which have an authority to make decisions which have a legally binding character, even the highest forum in the UN -The General Assembly- does not have that kind of authority. The UNSC have that authority based on the UN Charter as mentioned above. Moreover, related to the international threat, they have its authority based on Chapter VII at Article 39 which states that "The Security Council shall determine the existence of any threat of peace ... to maintain or restore international peace and security". That authority means that the UNSC have a material or legal to control every self-defenses or force actions to ensure international peace and security [2].

Terminology of threat itself can be interpreted as "communicated intent to inflict harm or loss on another's property... diminish a person's freedom to act voluntarily or with lawful consent"'[3]. Thus, based on that interpretation, from views of this study, the international threat can be explained as an act which can inflict harm or eliminate peace in the level of international and there is an intention to do it.

UNSC, the UN organization which have the authority to determine a threat to peace, in international context -based on UN purpose- is basically cannot or even does not have any benchmarks about term "international threat" itself. When we looking for it -because of- the United States of America (USA) point of view, they have their own definition toward a threat itself by divided it into two distinctions, which is; global threats (by type of act i.e. cyber threat, emerging technologies which is disruptive, terrorism, weapon of mass destruction and proliferation) and regional threats (by countries i.e. China, North Korea, Russia and Eurasia, Middle East and North Africa) [4]. In the other view, international threat are defined as international terrorism, health and pandemics, international migration, environmental security, and energy security [5].

\subsection{General Views on Unjust War}

Unjust War itself is not a new concept in international humanitarian law, in fact that is the new term in the international humanitarian law engaged by Michael Walzer in late 1970. The reason behind that idea is his turmoil on the divided side of war rules when it was started on medieval age and its stands still until now. In fact, the Unjust War is some kind of breakthrough on international humanitarian law, it is not just on terminology only but giving the different perspectives to it. When classical "laws of war" divided into two different kinds of law, jus ad bellum and jus in bello, it leaves some mark that the community always engage 
on development of jus in bello only, leaving the jus ad bellum behind on the conservative ways, never changed at all.

The Unjust War term in reality receives some critics, when some nations argue and simplify that there is a difference between the two rules of war to them. Sort a judgment about that is the possibility between a just war can be fought unjustly and the unjust war can be fought in strict accordance to the rules [6]. A jus ad bellum concept which was developed in seventeenth century. This concept only explains that the characteristic of the war classified as a Just War or the right war, it is comply to five elements including; just cause; right authority; right intent; proportionality; last resort [7]. Other view maybe to made it clear that the Unjust War term is more significant than the middle age concept of the just war. The differences between them are, the Unjust War raised the fundamental question about moral and legal vocabulary term use of war itself or even difference between severity and cruelty, all of them was the philosophical question of war itself [8], in addition Unjust War term is including the ability to act morally to the others, signal to strengthening of idealism moreover to reconstruct post war environment, human rights individuals are recognized and respected [9]. Based on that opinion, it is known that the concept on Unjust War is deeper than the ordinary or classical concept on war because the consideration of war is cannot just divide into two laws that frequently like straddle to each other. The war itself must be regulated clearly not only how to conduct a war itself -as many scholars always focused on, but it is also about how to wage a war. Logically, there is no the regulation used on how to conduct a war, moreover, the destruction or the effect when the war is successfully prevented by series of detail rules of the common authorities.

\section{Objective of the study}

The authority to determine an "international threat" does not have a benchmark used by main countries on the UN Security Council to meet up their political interests. This study aims to construct the International Threat in which, this is included to the UN Security Council Authority. This authority is mostly only ended on states which has a veto right in the UNSC. There must be clear measurements to set it, so that the authority is not used only to serve the political power or to fulfill the interest of states which are benefited by the existing authority on the UNSC. Construction of that authority is important to prevent big countries to not wage a war for no reason because that authority is not detail to be implemented in every international affair where suspected to qualify as international threat.

\section{Methodology}

This study uses the normative research method, which is part of legal research. A normative legal research is used to find a solution from the arising legal issues and to give a prescription to the legal issues.[10] This research aims to construct the authority of the UNSC regarded to the international threat which is the determine authority is on the scope of normative research since there is unclear aspects on that authority. The purpose to make it clear is to prevent an unjust war, in which it has destructive results when the authority is not obeyed by the main countries which involved in the war. Constructing arguments will be used in this study which is composed by summarizing texts; choosing amongst appropriate texts for the most useful; research and organization of texts; critique and analysis; and the appropriate collection to persuade the validity of the arguments presented. In short, to delicate balance between facts and/or theories as well as the application of existing rules [11]. 


\section{Discussion}

Waging a war for many scholars and commonly in custom are considered as the last effort to solve a problem or dispute between any parties, in this context is the country itself. History has dragged the human race to various war that lead to unimaginable destruction and loss. The build-up of the UN itself, as written in the charter, recorded that there are two world wars happened which has brought untold sorrow to mankind. Thus, to prevent this kind of war happens, the UN which is the common organization consisted of almost all the countries in the world, is designed to reach the common purpose and moreover no more world war again.

Indeed, as far as development of UN especially the world society, the UN functions hardly reach its honorable path. This statement comes since the UN and other constituent bodies were sometimes complemented, spurred, and inhabited by those of other actors in political world [12]. From that point of view, we all know that the legally binding decision of the UN itself is shackled by the politics' interest. The enormity use of the politics on decision making in the UN is the legacy from the big countries who won the war and the establishment of the UN itself mostly because of role of politics and power, in the international relations called the classic realism approach [13]. The phrase of international threat, in which the UNSC has authority to determine, mostly dominated by the big five countries who have the veto power, mainly USA and Russian Federation. As we see, those two countries always defend their own or its allies' interest, like the UNSC draft resolution towards Jerusalem and Palestine, or draft resolution on MH17 Shootings Tribunal. The main purpose of Veto rights itself is that the country which hold the right must be stand on inescapable fact of power differentials [14] or in simple word, the five countries have the biggest responsibility to guarantee the world peace and security, while they should not to use it as a political interest power.

The difficulties in using the legal argument on the UN, back to discussion above are, that the law simply does not deal with the question of ultimate power but also discovered of the political realm, when states use their force against other states, they also use the international law to defend their interests, argue and counter, explain and rationalize their action [15]. The UNSC itself which has the power to made a decision which is charged as legally binding can be said as the legislator on the UN, for example the establishment of ICTR and ICTY because of UNSC consideration that the incidents in these two places can be categorized threats to peace such protection of civilians in civil wars, violations of human rights and state terrorism [16], but why that considerations can be formulated into what is the international threat means? The answer is because it was interfered with big countries interests. When the threats coming from emerging country then there's always a protest or intervention from them, when it was interfered with their interest, they'll call it sovereign rights. The values of universality i.e. justice, independent etc. (in which the greater countries always promote to) sometimes cannot reach its goals. Moreover, the challenge to universality posed by a new states (Post World War II) not because the different of culture but different of interest [17], over and over, emerging countries often fall as the victim.

As we know from the fact above, the veto rights which is held by the big five, is the usual problem in the UNSC and seems to undisturbed, so which way we should go through to find a solution to this double standard regime on the UN? History told us that the big five, mainly the US and Russia conducts a serious violation that lead to unjust war, such as Afghanistan in mid 1980s, Iraq on 2001, even Syria conflict 2011-now. That is all happen because of the weakness of the legal formulation regarded to the international threat. Interpretation on international law better described as an art not science because actually there are no rules on principles upon it to be applied in a particular set of circumstances [18]. Facing on that fact, it seems there is no way out to determine what is international threat in the international society, but from CLS deconstruction approach which is the main idea is, "text never have 
an objective significance" and must defeat determination of the text and delegitimize liberal claims on law [19], we can deconstruct international threat issues with a legal and action plan.

First, of course we always determine to erase the veto rights from the UNSC authority to make sure the equality views on decision making on every UNSC draft resolution, for the common purpose. Second, based on article 41 and 42 UN Charter, the rest of the country in UNSC or outside it, can apply some sanctions toward the "naughty action" which is conducted mostly by the big five to its interests abroad. The important thing is that the delivering of the sanctions must have its own alliance so that country which insists to use the force without UNSC authorization is suffered the bilateral consequences for their action. Since there is an interest to protect the human rights or other sovereign equal state, while the main purpose of an unjust war is mostly to emboldened tyrants [20]. Third, issue a condemnation through UN General Assembly and towards the attempt to redefine the international threat by legal scholar from all states -or propose through International Law Commission- so there is a legal and official interpretation or benchmark on international threat phrase. Fourth, revitalize the role of the big five in intervening the country which allegedly or suspected waging a use of force as mentioned on article 2 section 4 without UNSC authorization.

\section{Conclusion}

The United Nations as an international organization played an important role to defend the world peace and security. Although, there is a heavy challenge to create a benchmark of international threat so that the bigger countries cannot wage an unjust war to other countries. There must be a will to resolve it through deconstruction of the Article 39 formulation. Agenda to remove a veto rights, giving the disobey country a sanction, condemnation in the UN General Assembly and agenda to propose a benchmark for international threat phrase and possible ways to intervention when there is a country indicated using force without UNSC authorization. That sequences ways need to be applied not only to make UN more effective toward its purpose, but also above all to protect human dignity and respect the equality of sovereignty to all members of the UN.

\section{References}

1. K. J. S. Ozgercin, “Toward a More Secure World? The Report of the High Level Panel on Threats, Challenges, and Change," (Berlin, 2005).

2. J. Allain, Max Planck Yearbook of United Nations Law, 8. (Leiden: Martijnus Nijhoff Publishers, 2004).

3. B. A. Garner, Blacks Law Dictionary (8th Ed. Pennsylvania: West Group, 2004).

4. D. R. Coats, "Worldwide Threat Assessment of the US Intelligence Community - Senate Select Committee on Intelligence," (Washington, 2017).

5. N. Babayan, "New and Envolving Trends in International Security," 13 (Rome, , 2013).

6. M. Walzer, Just and Unjust Wars, A Moral Argument With Historical Illustrations, Fourth Ed. New York: Basic Books, 1977.

7. K. Haryomataram, Pengantar Hukum Humaniter, Third Ed. Jakarta: Raja Grafindo, 2005.

8. R. Howse, "Thucydides and Just War: How to Begin to Read Walzer's Just and Unjust Wars, ” Eur. J. Int. Law, 24, 1, p. 18,19,22, (2013).

9. B. R. Banta, "Just War Theory and the 2003 Iraq War Forced Displacement," J. Refug. Stud., 21, 3, p. 263 (2008).

10. D. O. Susanti, Penelitian Hukum (Legal Research). (Jakarta: Sinar Grafika, 2014). 
11. S. Hanson, Legal Method \& Reasoning (2nd Ed. London: Cavendish Publishing Limited, 2003).

12. S. N. McFarlane, Human Security and The UN - A Critical History (Indiana University Press, Bloomington, 2006)

13. U. S. Bakri, Dasar Dasar Hubungan Internasional (Kencana Prenada Media, First Ed. Jakarta, 2017)

14. D. Bowett, Hukum Organisasi Internasional (1st Ed. Sinar Grafika, Jakarta, 1991).

15. D. Kritsiotis, The Politics of International Law (Cambridge University Press, Cambridge, 2004)

16. M. L. de L. S. Galvan, "Interpretation of Article 39 of the UN Charter (Threat to Peace) by the Security Council. Is the Security Council a Legislator for Entire International Community?,” Anu. Mex. Derecho Int., XI, p. 153 (2011).

17. A. Anghie, Imperialism, Sovereignty and the Making of International Law. (Cambridge University Press, Cambridge, 2004).

18. C. F. Amerasinghe, Principles of Institutional Law of International Organization (Second Ed. Cambridge University Press, Cambridge, 2005).

19. A. M. Fajar, Teori Teori Hukum Kontemporer, 3rd ed. (Setara Press, Malang, 2016).

20. T. Nardin, "The Right to Intervene to Duty to Protect: Michael Walzer on Humanitarian Intervention,” Eur. J. Int. Law, 24, 1, p. 72 (2013). 